\title{
"You shouldn't worry walking a block and a half to your car": 1 Perceptions of Crime and Community Norms in the Bakken Oil Play
}

\author{
Jessica D. Ulrich-Schad \\ Assistant Professor of Sociology and Rural Studies \\ South Dakota State University \\ Brookings, SD 57007 \\ Michael Fedder \\ South Dakota State University \\ Brookings, SD 57007 \\ Julie Yingling \\ Assistant Professor of Sociology and Rural Studies \\ South Dakota State University \\ Brookings, SD 57007 \\ Contact author: Jessica D. Ulrich-Schad: jessica.schad@sdstate.edu
}

\begin{abstract}
The Bakken oil play ${ }^{2}$ experienced substantial population growth from oil and gas development over the last decade, resulting in disruption to social norms at the community level. We surveyed residents in a county in Montana and a county in North Dakota about their perceptions of crime resulting from the most recent boom, finding that residents perceived high levels of various types of crimes resulting from the boom and that many also changed their daily behavior out of fear of such crime. In addition, we asked about current perceptions of community norms and find evidence that perceived levels of helping and trust are lower in the boomtown context than in other similar types of rural areas. We also show how these perceptions matter for other important community-level issues; those who perceived high levels of crime were more likely to see energy development as negative and those who saw community norms as weaker and were less involved in community organizations were more likely to plan to leave. A better understanding of how residents perceive social disruption resulting from energy development and the implications of these perceptions can help leaders in rural boomtowns make better decisions related to natural resource development.
\end{abstract}

Keywords: boomtown, energy development, rural crime, social disruption, Bakken oil play, community norms 


\section{Introduction}

Imagine a situation in which people living in a rural, relatively isolated, community experience an economic and demographic boom driven by energy development which drastically and rapidly changes daily life. This boom brings significant economic growth in the form of jobs and taxes and the population swells as people move there to pursue new jobs and a new life. Hotels and apartments sprout up and over-crowd, rent prices soar, and grocery stores sell out of product before the end of the day. Farmers sell their land for development and local bars and restaurants fill up with newcomers. Residents who felt comfortable in their community now avoid some public places where faces are no longer familiar. While tempered since 2014, partly because of a drop-in oil and gas prices, such economic and social shifts occurred during the most recent oil and gas boom in the Bakken oil play in the United States (U.S.), which includes parts of North Dakota and Montana.

While energy development is not new to this region, the level of population and economic growth experienced during the boom from 2008 to 2014 was unprecedented. For example, in reference to the two study counties for which we report findings in this article, from 2010 to 2014, Williams County, North Dakota, grew by 44 percent and Richland County, Montana, grew by 19 percent (U.S. Census Bureau data). Some estimate that this uptick in production created nearly 70,000 jobs directly and indirectly in the Bakken area (Munasib \& Rickman, 2015). The popular press reported on often sensationalist, but important to understand, social disruption in the area from the oil and gas development, including the building of "man camps" to house the influx of workers, drug-fueled crime, and increases in crimes against women (see, for example, Eligon, 2013; Horowitz, 2014; Layne, 2014; Martin et al., 2019; Shepard, 2013). Conditions such as these have made the Bakken region ideal for studying how social norms and rules that underlie everyday life in relatively rural communities are disrupted amidst significant economic and demographic shifts.

There is evidence that some types of crime have risen in the Bakken region because of recent oil and gas development (Archbold, 2015; Martin et al., 2019; North Dakota Attorney General's Office, 2012); however, there are notable limitations to the conclusiveness of much of these data. Research indicates growing anomie in the area as a result of the recent boom (Jones, 2016), which Durkheim (1897) defined as conditions in which social and or moral norms are confused or simply not present. There is limited quantitative information, however, regarding how the oil boom has impacted perceptions of crime and anomie in the area as well as how these perceptions matter in important community outcomes, such as plans to migrate and support for oil and gas development. Given this context, a better understanding of how residents feel about community life, including their perceptions of safety and crime are warranted. We use data from a 2016 survey of residents of two counties in the Bakken oil play to examine these questions while also drawing comparisons to other rural U.S. places on some issues. A better 
understanding of how residents perceive social disruption resulting from energy development and the implications of these perceptions can help leaders in rural boomtowns make better decisions regarding natural resource development.

\section{Literature Review}

\section{Sociological research on energy boomtowns}

Rural sociologists such as Freudenberg $(1981 ; 1982 ; 1984)$ have long been interested in the social consequences of population growth in rural "boomtowns" throughout the U.S. While positive outcomes such as rising employment and wages, increased tax revenue, and infrastructure investments are often related to these linked demographic and economic shifts (Fernando \& Cooley, 2016a), such dramatic change can also disrupt social life in longstanding rural communities. The social disruption hypothesis (England \& Albrecht, 1984) or model used by many (Merrifield, 1984; Park \& Stokowski, 2009) contends that communities experience problems with a rapid influx of new residents that can alter established norms and social structures and cause significant changes in the composition and dynamics of the local population. For instance, this body of work has shown that rapid population growth, paired with industry development increases stress of residents, leads to residents changing their patterns of interaction in their community, can change a community's identity, and can even decrease community strength and support (Brasier et al., 2011). Other studies have indicated that the quality of community services declines (England \& Albrecht ,1984), there can be community-level mental health consequences (Freudenberg et al., 1982), and that men and women can experience the boom differently (Freudenberg, 1981). Research on energy boomtowns has also documented increased criminal behaviors (Ruddell, 2011), strain on police and other public services (Anderson \& Theodori, 2009; Brasier et al., 2011; Fernando \& Cooley, 2016b), increased domestic violence (Endo et al., 1984), increased violent crime rates (Carrington et al., 2012), and increased drug and alcohol abuse and mental health issues (Bacigalupi \& Freudenberg, 1983; Carrington, Hogg, McIntosh, \& Scott, 2012). Overall, studies indicate that various dimensions of residents' well-being are impacted differently in the boom-bust context, can be based on proximity to development (Junod et al., 2017), and are not necessarily long-lasting (Smith et al., 2001).

One study conducted in an Australian mine boom town found that rural community members felt a great deal of animosity toward the non-residential workforce due, in part, to the breakdown of local services and various social divisions within (Carrington et al., 2012; Scott, Carrington, \& McIntosh, 2012). The social services in the small towns were funded based on the number of permanent residents. Not only did the influx of workers not gain the community any additional resources, but the non-resident workforce caused problems for existing community services. For example, the camps were self-sufficient and used private contracts for cleaning, 
food, and alcohol (Carrington et al., 2012). Residents referred to this as a fly over effect to the local economy in that no local businesses were supported by the influx of miners. Additionally, the increase in miners caused an increase in hospital emergency cases as the men were frequently injured from fighting, being too drunk, and using drugs (Carrington et al., 2012). Locals associated the community problems with the transient workers (Carrington et al., 2012; Scott et al., 2012). The miners worked long hours and then spent their leisure time fishing and playing with disruptive toys (e.g. boats, trucks, fast cars). Locals were incensed that the miners did not engage in local activities and their frustration with this frequently boiled over into fights, hostility, and negative perceptions (Carrington et al., 2012; Scott et al., 2012).

There is a well-established yet still growing body of literature surrounding energy development in the U.S., including the Marcellus Oil Shale in the Northeastern U.S. (see, for example, Braiser et al., 2011; Jacquet \& Stedman, 2011; Malin, 2014; Perry, 2012; Schafft, Borlu, \& Glenna, 2013; Schafft, Glenna, \& Borlu, 2014), and other oil fields such as the Eagle Ford Shale in Texas (see Anderson \& Theodori, 2009; Ellis et al., 2016; Theodori, 2009; Wynveen, 2011), yet comparatively less has emerged from the Bakken area which experienced a more recent boom, driven in part from new fracking and horizontal drilling technology. The relatively geographic and socially isolated nature of this particular oil play also make it important for examining the impact of rapid energy development on more isolated rural communities.

For their studies in the Bakken area, Fernando and Cooley (2015, 2016a, 2016b) used content analysis of local newspaper opinion articles and online comments, interviews with residents, and observations to explore the impact of the recent boom in western North Dakota. One study (Fernando \& Cooley, 2015) focused on how the Bakken oil boom impacted residents' quality of life (QoL) and found that perceptions of QoL were related to whether residents were benefitting financially from the boom and whether they experienced an escalation in their cost of living (housing particularly). Notably, irrespective of benefiting from the boom, long-time residents felt a lack of safety and security, low levels of trust and unity among community members, and a change in the nature of social relationships in the community as a result of the boom. In another analysis, feelings of safety and security emerged as a prominent threat to the oil field communities, fueled by concerns regarding rapid population growth, overstretched law enforcement and public services, a disproportionate male to female ratio, the transient nature of the workforce, and increased crime and traffic (Fernando \& Cooley, 2016a). Fernando and Cooley (2016b) also found that it is difficult for new residents to integrate and establish ties and attachments to the community.

Other recent studies have focused on communities adjacent, but not directly part of, the Bakken shale. Junod et al. (2017) used interviews to study how oil development on the periphery of the Bakken Shale impacted residents' perceptions of place disruption. They found evidence of a "Goldilocks Zone" just outside of the core development communities where residents felt they 
benefitted somewhat economically from spillover effects yet did not experience the same negative social impacts. Other studies outlined below, both within and outside of the Bakken, have focused more explicitly on crime and/or perceptions of crime in communities in boom mode.

\section{Crime and perceptions of crime in oil and gas boomtowns}

Findings are mixed regarding the impact of boomtown growth on crime volume and severity. In general, studies from the U.S. and Canada show that levels of police-reported crime increase in boomtowns, yet there is much variation in its magnitude (Ruddell \& Ortiz, 2014). Popular media reports on the surge in crime in the Bakken region because of the oil boom abound. There is some evidence that some types of crime have risen in the Bakken region as a result of the development (Archbold, 2015; Martin et al., 2019; North Dakota Attorney General's Office, 2012), however, conclusive evidence about how crime rates have changed as a result of the boom can be problematic. First, Federal Bureau of Investigation (FBI) statistics based on the Uniform Crime Reports (UCR) woefully underrepresent crime, especially in rural areas (Maltz, 1999; McGranahan, 1986). The transition to the National Incidence-Based Reporting System (NIBRS) is increasing the validity of crime rates for both urban and rural communities (Faggiani \& McLaughlin, 1999), but slowly and incompletely. For example, Martin et al. (2019) found that only 37 percent of US police departments reported crime statistics to NIBRS in 2016.

Second, research indicates oil and gas development does increase crime (Archbold, Dahle, \& Jordan, 2014; Carrington et al., 2012; James \& Smith, 2017; Martin et al., 2019; Ruddell, 2011; Ruddell, Jayasundara, Mayzer, \& Heitkamp, 2014; Scott, Carrington, \& McIntosh, 2012), with police services stretched increasingly thin and given little or no additional resources to address new crime issues (Archbold, Dahle, \& Jordan, 2014; James \& Smith, 2017; Ruddell, 2011). The lack of UCR or NIBRS data in these rural locations makes longitudinal trends difficult to determine (James \& Smith, 2017; Ruddell et al., 2014) while booms on tribal land suffer from even less official crime data as tribal crime data are only sporadically reported to the FBI (Indian Law \& Order Commission, 2013).

Overall, boomtowns tend to experience an increase in the volume of calls for service by police (Archbold et al., 2014; James \& Smith, 2017; Ruddell, 2011; Ruddell et al., 2014). Research shows boomtowns experienced an increase in all crime categories except burglary (James \& Smith, 2017), but a small increase in: violent crimes (e.g., rape, robbery, and murder), aggravated assault, and grand auto theft (James \& Smith, 2017; Martin et al., 2019); violent and property crime (Martin et al., 2019; Ruddell et al., 2014); domestic violence (Archbold et al., 2014; Martin et al., 2019), as well as alcohol intoxication and traffic-related offenses (Archbold et al., 2014). In their examination of crime data in the Bakken oil-producing region, Martin et al. (2019) found that that violent victimization (e.g., murder, rape, sexual assault, unlawful sexual 
contact, robbery, assault, kidnapping, and intimidation) rate rose by 31 percent for men and 18 percent for women between 2006 and 2012. During this same time period, the violent victimization rates in non-Bakken counties of North Dakota, South Dakota, and Montana decreased by eight to ten percent (Martin et al., 2019). Additionally, the type of labor available in oil and gas developments can attract people with a criminal history to the area (e.g., criminal migration). For example, James and Smith (2017) found that a number of registered sex offenders migrated to shale-rich counties because work is available for individuals regardless of criminal background. However, the specific impact of these former offenders on the increasing crime rates in oil and gas developments is unknown. Conversely, an Australian mining boom town saw an increase in violent crime, but a decrease in reporting. Researchers (Carrington et al., 2012; Scott et al., 2012) found that bar and club patrons conspire with the licensed operators of those establishments to prevent police involvement and threats to business licenses.

Further, population growth, not only in energy boomtowns, can lead to perceptions of increased crime (Brown, 2011; Kennedy \& Krahn, 1984). Studies in energy growth communities outside of the Bakken oil play have also focused on how residents perceive crime and disorder (O'Connor, 2015; Ruddell \& Ortiz, 2014). Ruddell and Ortiz (2014) found that more residents of a boomtown thought that crime had increased in their community than respondents to a general survey of Canadians, and that their worries about crime decreased along with actual crime rates over the study period. In a qualitative study of perceived social change in Fort Murray, Canada, O'Connor (2015) found that women were more worried than men about risks to their personal safety because of the influx of population.

While perceptions that safety and security decreased emerged in many studies focused on the broader social impacts of energy development in the Bakken (e.g., Fernando and Cooley, 2015; Fernando \& Cooley, 2016b), a study by Archbold (2015) explicitly examined how police in the Bakken region thought crime had changed since the oil boom. Many law enforcement officers described alcohol as being a big factor in the crime they responded to since the oil boom. They also reported a sharp increase in assaults. One officer noted that the assaults involved increasingly dangerous weapons and were more often between strangers. This same study concluded by noting the social division between new and long-term residents. Archbold (2015) concluded that negative stereotypes were reinforced by town gossip and may have led to increased perceptions of crime caused by new residents.

Another study by Archbold, Dahle, and Jordan (2014) focused on analyzing types of crime occurring during the boom through interviews with police members of a department operating in a North Dakota boomtown. The authors found that alcohol related crime was the most frequent, noting that frequent bar fights would break out between groups of oil field workers. The law enforcement officers commented that many long-time residents are afraid to go out at night as a result. The second biggest crime issue faced by law enforcement during the boom in the Bakken 
was drugs, specifically methamphetamine. They indicated that one in every five criminals they dealt with were carrying illegal drugs of some kind. The study concluded by noting the significant changes to police department operations in the boomtowns of North Dakota.

Jones (2016) examined the relationship between crime and suicide in the boomtowns of the Bakken region. The study found rising crime rates in addition to rising rates of suicide. Jones (2016) applied Durkheim's theory of anomie as an explanation for the rising crime and suicide rates. He argued that anomie stems from rapid social changes that disrupts pre-established societal roles. When these roles are disrupted there is need for new organization, however, the boomtowns may be unable to effectively reorganize societal roles to match the huge economic growth and social change. Hence, according to Durkheim (1897), anomie increases, and so does suicide and crimes that are violent and self-destructive in nature.

While the body of research on the social impacts, including real and perceived crime, of energy development in general and in the Bakken area, is growing, much of it is qualitative. Quantitative methodologies, such as a probability sample survey of residents, can provide a more representative picture of how economic and demographic changes resulting from the boom affect the perceived quality of living of both old and new residents living in the Bakken oil play region. The purpose of this study is to use survey data to further understand perceptions of crime and community in the context of the rapidly increasing and changing population in the Bakken region as well as how they relate to important factors such as residents' intentions to migrate and their views on oil and gas development. Existing studies have focused on how the perceived risk of social disruption or impacts may influence beliefs regarding future oil and gas development and vice versa (Evensen \& Stedman 2017; Devine-Wright \& Howes, 2010; Jacquet \& Stedman, 2013; Sangaramoorthy et al., 2016), but have not examined how perceptions of crime impact attitudes about local energy development or intentions to migrate quantitatively.

\section{Research Questions}

Given the lack of generalizable knowledge about the extent to which the recent boom in the Bakken has impacted residents' views on crime and safety, this study seeks to answer the following research questions: 1) How do residents perceive crime in their community in relation to the recent oil boom? 2) How have residents changed their behavior to feel safer as a result of the recent oil boom? 3) How has the oil boom affected perceptions of community norms and civic engagement? And finally, 4) Do perceptions of crime and community norms play a role in whether residents plan to migrate in the future and their overall attitudes about oil and gas development in the area? This type of information can be useful to community planners in rural boomtowns as they address some of the long-term planning issues associated with boom and bust economies and natural resource development. For instance, if positive perceptions of community norms play a role in keeping both new and long-term residents in the community, planners might 
strive to involve more community members in local groups or efforts or make them aware of available resources or initiatives.

\section{Methods}

\section{Data collection}

The findings from this study are derived from a 2016 mixed-mode survey conducted in two counties in the Bakken oil play, Richland County, Montana and Williams County, North Dakota (see Figure 1). Williams County was selected because of its centrality in the oil and gas boom in the area, particularly the town of Williston. Richland County was selected to provide a contrast county that still experienced the boom, but to a lesser degree. A random sample of residents from each county were purchased from InfoUSA (Williams=1,000; Richland=850). Excluding bad addresses, we had a 26 percent $(\mathrm{N}=397)$ response rate to the survey. This is within the range of other social science surveys focused on shale oil and gas development (Fernando, Ulrich-Schad, \& Larson forthcoming). Using a modified Dillman et al. (2013) tailored design, the survey was mailed out in four waves every two weeks during the fall of 2016 (advance letter with option to take the survey online, first paper copy of survey with a stamped return envelope, reminder postcard, and second copy of mail survey). To account for the disproportionately high response rate from male and older residents, we applied age, race, and sex weights using 2015 American Community Survey county data in all analyses.

The survey questions were designed to be similar to Community and Environment in Rural America (CERA) surveys conducted in rural places throughout the U.S. by the University of New Hampshire's Carsey School of Public Policy from 2007 to 2011 (see, select publications using this data: Hamilton et al., 2008; Hamilton, Safford, \& Ulrich, 2012; Safford et al., 2014; Safford, Ulrich, \& Hamilton, 2012; Ulrich-Schad \& Duncan, 2018; Ulrich-Schad \& Qin, 2017; Ulrich-Schad, Henly, \& Safford, 2013). Nearly 17,000 rural Americans were surveyed over the telephone in this project from a variety of geographically and economically diverse rural places. The aim of these surveys was to gauge rural residents' perceptions of the economic, social, and environmental changes occurring in their communities and allow for comparisons between different types of rural places. As described in greater detail by Ulrich-Schad and Duncan (2018), counties surveyed include those rich in natural amenities which are growing in population ("amenity rich"; 13 counties, six states, $\mathrm{N}=4893$ ), areas undergoing profound economic and demographic transitions ("transitioning"; 16 counties, seven states, $N=7028$ ), and chronically poor areas which have experienced underinvestment and outmigration in recent decades ("chronically poor"; 10 counties, four states, $\mathrm{N}=4896$ ). We used some identically 

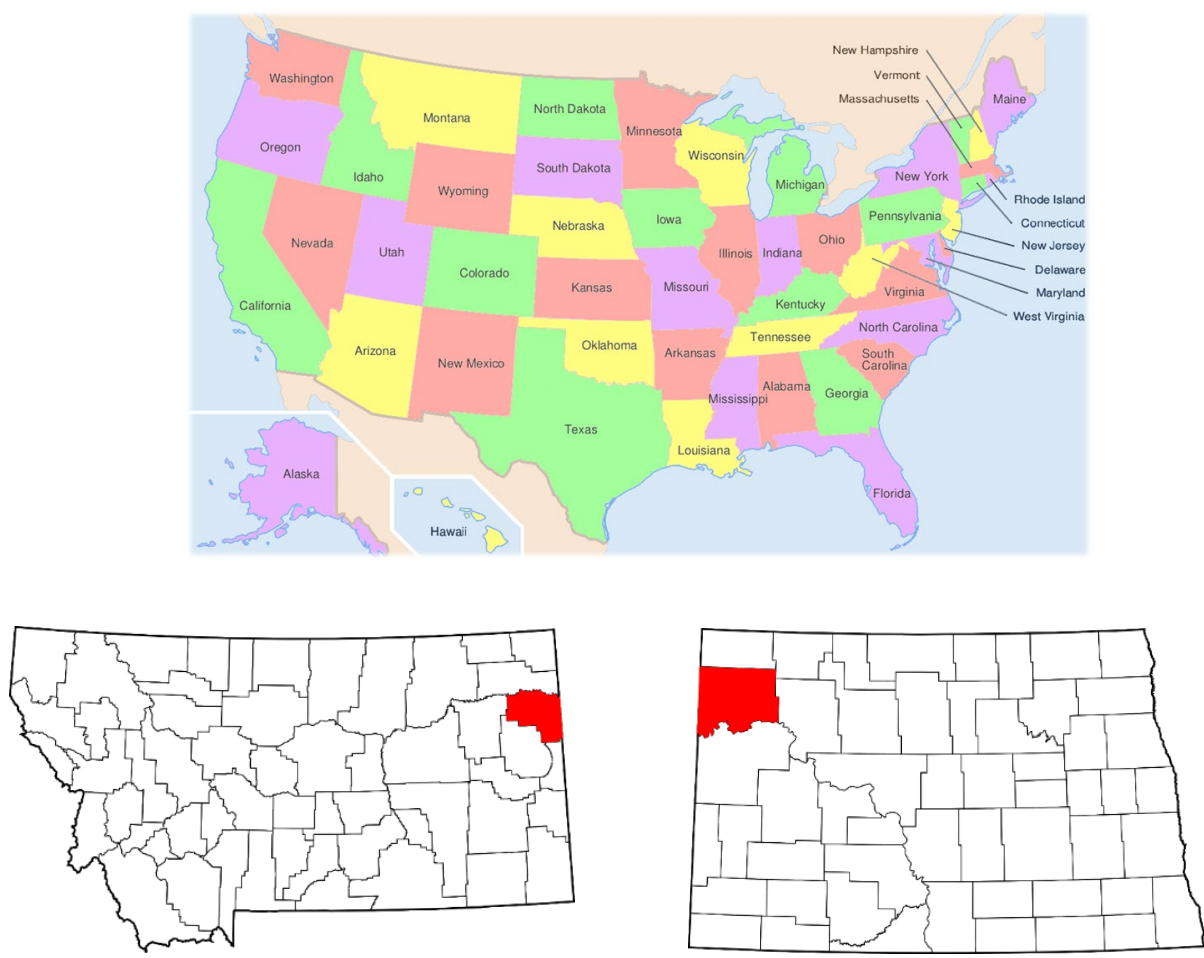

Figure 1: Maps of States and Study Counties (Montana on left and North Dakota on right) ${ }^{3}$

worded questions in the Bakken study but also added questions pertinent to oil and gas development in the region. Later in this paper we refer to the CERA survey conducted in the Bakken oil play as the "Bakken CERA" survey and the data from other rural places surveyed as simply the "CERA" survey.

In the following sections we will discuss the survey questions that are not included as part of the multivariate analysis, then discuss independent variables, control variables, and dependent variables used.

Behavior changes to increase feelings of safety: In-depth interviews conducted in the area to help increase the relevancy of survey questions indicated that some residents were changing their normal behavior in response to the real and perceived changes in their communities resulting from the oil and gas boom. To get a better account of how widespread these changes were we asked survey respondents if they had started (yes or no) doing any of the following nine behaviors to make themselves feel safer as a result of the development: purchased a new vehicle, stopped going to local places (e.g., restaurants, bars), stopped walking alone, started locking house doors, installed alarm system, installed motion lights, purchased firearm, started carrying lethal protection (e.g., gun), or started carrying non-lethal protection (e.g., pepper spray). 


\section{Independent variables}

Perceptions of crime: Survey respondents were asked whether they saw ten different problems as present in their community (violent crime, property crime, manufacturing or sales of illegal drugs, public drinking or drug use, prostitution, human/sex trafficking, homelessness, panhandling or begging, vandalism or graffiti, and gangs) and whether they attributed their presence to recent oil and gas industry development (no, partially, yes). In our multivariate models, we used a perceptions of crime index which is a composite measure summarizing the responses to these ten questions. Scores on the index range from 0 to 30 with a mean of 17.6. The Cronbach's alpha score is .91, an excellent level of internal consistency.

Community norms: Respondents' were asked whether they agreed with the following statements (yes or no): 1) "If this community were faced with a local issue such as the pollution of a river or the possible closure of a school, people here could be counted on to work together to address it," 2) "People around here are willing to help their neighbors," and 3) "People in this community generally trust one another and get along." In our multivariate models, we use an index ("community norm") comprised of these three questions. Scores in this index range from 0 to 3 with the mean response a 2.6. The Cronbach's alpha score is .68, at the lower end of acceptable scores. We also asked residents whether they belong to any local organization which has local meetings. ${ }^{4}$ Given that we did not ask whether these community factors changed as a result of the recent oil and gas development, we show how levels in the Bakken area compare to other rural places to explore the relationship between the boom and perceptions of community helping norms and involvement.

\section{Control variables}

In our multivariate models, we control for respondents' county of residence (Richland=1; Williams $=0$ ), gender (male $=1$; female $=0)$, age (continuous), marital status $(1=$ currently married; $0=$ not currently married $)$, highest level of education $\left(1=8^{\text {th }}\right.$ grade or less; $2=$ some high school; $3=$ high school graduate; $4=$ technical school; $5=$ some college; $6=$ college graduate; $7=$ postgraduate work), financial standing in comparison to 5 years ago ( $1=$ better off; $2=$ same; $3=$ worse off), current employment (or family member) in oil or gas industry ( $1=$ yes; $0=$ no), newcomer status (less than 10 years $=1 ; 10$ years or more $=0)$, belonging to a local group ( $1=$ yes; $0=$ no), score on community norm index (see above), score on perceptions of crime index (see above), scores on practical and natural community attachment indexes ${ }^{5}$, importance of staying for family $(0=$ not; $1=$ somewhat; $2=$ very $)$, advice to teens to leave for opportunities elsewhere $(1=$ yes; $0=$ no), and attitude about the community in the future $(1=$ better place; $2=$ the same; $3=$ worse place). Given the review of existing literature, we hypothesize that some of these variables will be significant predictors of our outcome variables, while others serve as control variables in our multivariate models. 


\section{Dependent variables in multivariate models}

Survey respondents were asked whether they plan to continue living in the area for the next five years, a standard time period used by the U.S. Census Bureau to calculate migration rates for various geographic divisions. Eighteen percent said they planned to leave, while 82 percent planned to stay. While this is not a direct measure of migration, it does indicate a desire or plan to leave which could be argued is generally reflective of how one feels about their current community and their prospects within it. It should be noted, however, that some may want to leave but lack the resources or ability to do so. We also asked Bakken area residents how much they agreed or disagreed with the following statement: "Overall, I would say that the recent oil and gas boom has been a positive thing for my community." Sixty-nine percent either agreed or strongly agreed with this statement.

\section{Data analysis}

We begin by simply describing the percentage of residents who saw various issues as problems in their community and the degree to which they attributed these problems to recent oil and gas development using the Bakken CERA data (see Figure 2). We also describe the percentage of residents who changed their behavior to increase their feelings of safety (see Table 1) using the Bakken CERA survey data. Next, using both the general CERA survey dataset and the Bakken CERA data, we examine the percentage of respondents who agree with the community norm statements and belong to a local organization (see Tables 2 and 4) and examine whether there are significant differences between the Bakken and non-Bakken rural counties (chi-square test of independence). Finally, we use weighted logistic regression models to examine relationships between independent variables and residents' intentions to migrate and views on oil and gas development in the Bakken oil play (see Table 5).

\section{Hypotheses}

Given the significant changes that have occurred within the area, we predict that a high percentage of residents will think various types of crime are problems in their area and that many will attribute the crimes to the recent oil and gas boom. We also hypothesize that perceptions of community helping norms may be low in comparison to other types of rural places, given the level of economic, demographic, and social change that has occurred. Finally, we hypothesize that both perceptions of crime and normlessness will be significant factors related to the outmigration of residents as well as unfavorable views of oil and gas development. 


\section{Results}

\section{Descriptive}

Perceptions of crime: We find that high percentages of residents of the Bakken area think that many types of crimes are a problem in their community (see Figure 2). For instance, the lowest percentage (about 50\%) see gangs as a problem in their community, while up to 95 percent see violent crime as a problem. Additionally, the majority of respondents also believe that such crimes are at least partially caused by the recent oil and gas development in their community. Of the types of crime asked about, violent crime and property crime are the most believed to be caused partially or solely by oil and gas development. Additionally, more than 70 percent of respondents believed human sex trafficking and prostitution are a problem caused at least partially by oil and gas development. Of that 70 percent, at least 40 percent believe that the oil and gas development are solely responsible for those crimes. The variation in respondents saying the different crimes are not a problem (indicated by green) is greater than those who say that various crimes are problems, but not caused by oil and gas development; in fact, the latter percentage is relatively constant across all crimes. For example, only five percent of respondents think the manufacturing or sales of drugs is not a problem in their community. Twenty-three percent indicate that drugs are a problem in their community, but not because of the oil and gas development. Further, nearly two-thirds of respondents think the drug problem in their community is completely or partially due to the oil and gas development. While this indicates where residents place blame for drug problems, it is important to note that residents do not

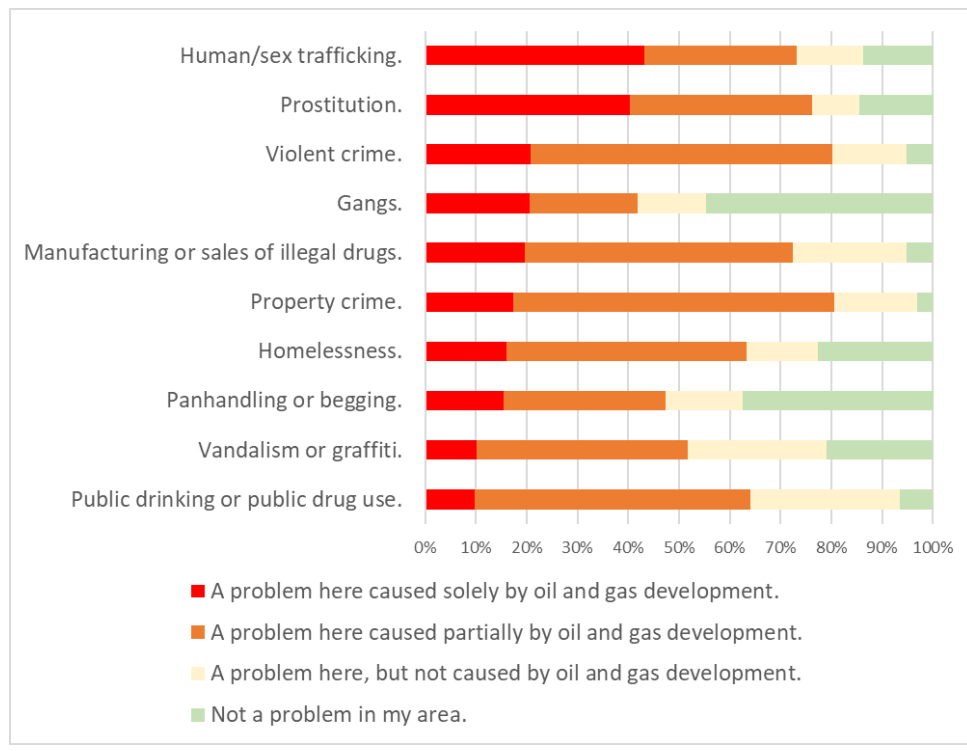

Figure 2. Perceptions of Problems and their Relation to Oil and Gas Development 
associate all problems with the oil and gas development. This indicates that the lower percentages we find for more serious crimes being caused at least partially by oil and gas development are due to fewer people having evidence of the crime being a problem in their community, rather than fewer people believing oil and gas development have at least partially caused it.

Behavior change to increase feelings of safety: Overall, residents made considerable changes in their daily lives to make themselves feel safer since the recent oil and gas boom began (see Table 1). The highest percentage (77\%) say that they started locking their doors. Consistent with the findings of Archbold, Dahle, and Jordan (2014), 30 percent of residents started carrying lethal protection.

Table 1. Percentage of Respondents Changing Behavior to Increase Feelings of Safety since the Start of the Oil and Gas Boom

\begin{tabular}{|l|c|}
\hline \multicolumn{1}{|c|}{ Behavior } & $\begin{array}{c}\text { Percentage of } \\
\text { Sample }\end{array}$ \\
\hline Started carrying lethal protection (e.g., gun). & $30 \%$ \\
\hline Purchased a different vehicle. & $31 \%$ \\
\hline Installed alarm system. & $35 \%$ \\
\hline Started carrying non-lethal protection (e.g., pepper spray). & $35 \%$ \\
\hline Installed motion lights. & $39 \%$ \\
\hline Purchased firearm. & $39 \%$ \\
\hline Stopped going to some places (e.g., restaurants, bars). & $45 \%$ \\
\hline Stopped walking alone. & $52 \%$ \\
\hline Started locking house doors. & $77 \%$ \\
\hline
\end{tabular}

Community Norms: We find that residents of the Bakken area perceive relatively strong levels of community cohesion and helping and nearly half are involved in local organizations (see Table 2). Specifically, nearly 80 percent say that people in their community generally worked together to address local problems, helped each other out when needed, and trusted each other and got along. The same questions were asked in CERA surveys conducted in other rural places throughout the U.S., allowing us to compare community norms in the Bakken area to other rural places. In comparison to all non-Bakken rural residents, residents of the Bakken area are less likely to support each statement about their community and slightly more likely to belong to a community organization. The difference between Bakken and non-Bakken rural residents is significant for the statement about trust and getting along, with Bakken residents being significantly less likely to say that they trust and get along with people in their community. 
Table 2. Perceptions of Community Norms in the Bakken CERA vs. Non-Bakken CERA Study Counties

\begin{tabular}{|l|c|c|c|}
\hline & Bakken & All Non-Bakken & Sig. Dif.? \\
\hline Work Together & $79 \%$ & $84 \%$ & \\
\hline Help Each Other & $89 \%$ & $93 \%$ & \\
\hline Trust and Get Along & $77 \%$ & $88 \%$ & $* * *$ \\
\hline Belong to Local Organization & $49 \%$ & $48 \%$ & \\
\hline$* \mathrm{p}<0.05 ; * * \mathrm{p}<0.01 ; * * * \mathrm{p}<.001$ & & & \\
\hline
\end{tabular}

Furthermore, despite being more similar to amenity rich and transitioning rural places in terms of socioeconomic and demographic indicators (see Table 3) when breaking down the CERA survey respondents by rural place type (described in methods section), community norms in the Bakken area are most similar to chronically poor rural places (see Table 4). Chronically poor rural areas often have weakened civic norms resulting from their histories of corrupt local politics and longstanding lack of investment (Duncan, 2015). While we cannot show direct causation, these findings suggest that recent oil and gas development may have disrupted community helping norms in the Bakken communities and be indicative of growing community normlessness and anomie as a result of the oil and gas development.

Table 3. Socioeconomic and Demographic Indicators for Study Counties in 2015, Percentage of Residents

\begin{tabular}{|c|c|c|c|c|}
\hline & $\begin{array}{c}\text { Amenity } \\
\text { Rich }\end{array}$ & Transitioning & $\begin{array}{c}\text { Chronically } \\
\text { Poor } \\
\end{array}$ & $\begin{array}{c}\text { Bakken } \\
\text { Counties } \\
\end{array}$ \\
\hline Population Change, 1990-2015 & 19.3 & 10.6 & -13.7 & 49.4 \\
\hline Adults 16-64 Working (full-time, year-round) & 41.1 & 42.6 & 36.0 & 58.8 \\
\hline Families with No Workers (past 12 months) & 20.0 & 20.6 & 27.8 & 7.6 \\
\hline Working Age (18-64) Men by Disability Status & 16.6 & 15.7 & 22.5 & 5.7 \\
\hline No High School Degree (25+) & 8.9 & 9.4 & 21.5 & 8.9 \\
\hline Associates Degree and Above (ages 25+) & 33.0 & 31.1 & 23.0 & 32.6 \\
\hline Median Household Income (in dollars) & 45,876 & 51,505 & 30,021 & 76,548 \\
\hline Single Female Family Households & 8.4 & 9.7 & 17.3 & 11.8 \\
\hline Children $(0-17)$ in Poverty & 22.2 & 21.0 & 38.4 & 14.7 \\
\hline
\end{tabular}

Source: 1990 U.S. Census data, 2015 American Community Survey 5 year estimates

Table 4. Perceptions of Community Norms Different Types of Rural Places

\begin{tabular}{|l|c|c|c|c|}
\hline & Amenity Rich & Transitioning & Chronically Poor & Bakken \\
\hline Work Together & $91 \%$ & $88 \%$ & $77 \%$ & $83 \%$ \\
\hline Help Each Other & $96 \%$ & $96 \%$ & $88 \%$ & $91 \%$ \\
\hline Trust and Get Along & $93 \%$ & $92 \%$ & $82 \%$ & $83 \%$ \\
\hline $\begin{array}{l}\text { Belong to Local } \\
\text { Organization }\end{array}$ & $59 \%$ & $52 \%$ & $43 \%$ & $53 \%$ \\
\hline
\end{tabular}




\section{Multivariate findings}

No variables have significant relationships with both plans to migrate and views on oil and gas development (see Table 5). In terms of predicting intentions to migrate, newcomers, those with high attachment to the quality of life and natural amenities, and those who would advise a teen to leave for opportunities elsewhere, are all at increased odds of planning to leave. Those who belong to a local group, who perceive strong community norms, and say family is an important reason to stay are all at decreased odds of planning to leave. Those who are worse off financially than five years previously and attribute the rise of many crimes to oil and gas development are less likely to see energy development as a positive thing for the community.

Table 5. Binary Logistic Regression Predicting Intentions to Leave and Views of Oil and Gas Development

\begin{tabular}{|c|c|c|c|c|c|c|}
\hline \multirow{3}{*}{$\begin{array}{l}\text { Variable } \\
\text { County (Richland) }\end{array}$} & \multicolumn{3}{|c|}{ Plan to Migrate } & \multicolumn{3}{|c|}{ Development Good } \\
\hline & \multicolumn{2}{|c|}{ Odds Ratio } & \multirow{2}{*}{$\frac{\text { Sig. }}{0.29}$} & \multicolumn{2}{|c|}{ Odds Ratio } & \multirow{2}{*}{$\frac{\text { Sig. }}{0.54}$} \\
\hline & 0.44 & & & 0.74 & & \\
\hline Gender (male) & 1.34 & & 0.62 & 0.84 & & 0.75 \\
\hline Age (years) & 1.01 & & 0.68 & 1.01 & & 0.61 \\
\hline Married & 0.75 & & 0.67 & 0.56 & & 0.33 \\
\hline Education level & 1.20 & & 0.38 & 1.03 & & 0.89 \\
\hline Worse off financially ( 5 years) & 0.71 & & 0.38 & 0.61 & + & 0.08 \\
\hline Work (or family member) in oil & 0.51 & & 0.30 & 2.18 & & 0.11 \\
\hline Newcomer (less than 10 years) & 12.21 & $* *$ & 0.01 & 1.76 & & 0.41 \\
\hline Belong to local group & 0.24 & $*$ & 0.02 & 0.75 & & 0.51 \\
\hline Community norm index & 0.49 & $*$ & 0.02 & 1.17 & & 0.56 \\
\hline Perceptions of crime index & 0.98 & & 0.64 & 0.91 & $*$ & 0.02 \\
\hline Natural/life quality attachment index & 4.18 & $* *$ & 0.01 & 0.89 & & 0.72 \\
\hline Practical attachment index & 0.95 & & 0.87 & 0.91 & & 0.74 \\
\hline Stay for family & 0.36 & + & 0.06 & 1.10 & & 0.83 \\
\hline Advise teen leave & 9.40 & $* *$ & 0.00 & 0.84 & & 0.71 \\
\hline Pessimistic about future & 1.05 & & 0.93 & 0.88 & & 0.69 \\
\hline Plan to migrate & - & & - & 0.82 & & 0.79 \\
\hline Oil and gas development good & 0.37 & & 0.37 & - & & - \\
\hline Constant & 0.75 & & & 21.12 & & \\
\hline McKelvey and Zavoina's R-squared & 0.64 & & & 0.26 & & \\
\hline Hosmer-Lemeshow chi-squared & 74.00 & $* * *$ & & 4.65 & $* * *$ & \\
\hline $\mathrm{N}$ & 229 & & & 229 & & \\
\hline
\end{tabular}

\section{Discussion}

Because of the rapid and significant social and economic changes during the most recent energy boom in the Bakken oil play, residents perceive increased crime and have changed their 
behavior quite considerably as a result. Many feel less safe, which has led to precautions like avoiding certain public places, and avoidance in turn can lead to further alienation from their community and residents within it. There is evidence of growing normlessness as exhibited by relatively low perceptions of community helping norms and involvement in local groups. residents' perceptions of crime and community helping norms are important to understand, we find, because some are related to decisions to remain in a community and play a role in general attitudes regarding oil and gas development in the Bakken area.

Additionally, while about half of the residents in the Bakken counties we surveyed are involved in formal community groups, such levels of participation are more similar to chronically poor rural areas of the U.S., which in many other ways are very different from the Bakken counties we studied. Research shows that community disorganization often occurs during the early stages of a boom before communities have the capacity to adjust to the multitude of changes a boom can bring (Goldenburg, 2008; Hunter, Krannich, \& Smith, 2002; Pooley, Cohen \& Pike, 2004; Shandro et al., 2011). Fernando and Cooley (2015) found that low trust and unity among community members increased during the oil boom in the Bakken, and this research also suggests that community members can remain less engaged and worried about normlessness even years after the boom onset.

Some of our findings can be used by community planners and leaders to mitigate some of the negative impacts of energy boom and bust cycles. For instance, we found that those who belong to a local group and perceive strong community norms were at lower odds of planning to leave than those who did not belong to a local group or perceive lower community helping norms. Thus, efforts to integrate new and existing community residents into a wide variety of community organizations should be prioritized to help people feel more invested in the community. Additionally, using these local organizations to reach out to new members of the community to make them feel welcome, aware of local resources, and meet other residents could go a long way. These organizations should also focus efforts on helping long-term residents deal with some of the negative effects of the boom, including addressing some of the negative stereotypes that some have of new residents that can lead to further community conflict and disengagement.

\section{Conclusion}

Along with economic prosperity for some, recent oil and gas development in the Bakken oil play brought heightened worries about crime and subsequently changes to how residents live their everyday lives, view their future within the community, and perceive oil and gas development. As with any study, there are a number of limitations that should be addressed. As outlined by Smith et al. (2001) nearly 20 years ago, there remains a need for more longitudinal research at the community level examining impacts of natural resource development. Given we 
did not have longitudinal data that would allow us to better assess causality, our results are limited. Future research might return to the Bakken region to see if the impacts of the boom have dissipated as research by Smith et al. (2001) also indicates. Future research should continue to explore how residents perceive the effects of natural resource development at various stages of the development cycle, not just during the height of the boom. We show that even after an energy boom is well underway, residents still feel a sense social disruption that is impacting their quality of life, as well as the civic culture within the community. Programs to better integrate new and long-term members of a boom community should be implemented and scrutinized to evaluate whether they can play a role in increased community cohesion during a period of increased normlessness. While we know residents are concerned about a number of crime issues, some of which they blame on the oil and gas development, we cannot speak to any actual change in crime rates. Perceptions of crime and resulting behavior changes are crucial in understanding how people feel and perceive the change, but we cannot speak to the necessity or effectiveness of people's behavior changes to increase their feelings of safety. Additionally, other studies could examine how direct experience with a crime impacts attitudes and beliefs about oil and gas development and behavior change. 


\section{Endnotes}

${ }^{1}$ Quote from an in-depth interview conducted with a resident of a Montana community to help develop survey questions.

${ }^{2} \mathrm{~A}$ shale, or oil, play consists of a group of oil fields or prospects in the same region resulting from the same geological history (Stoneley, 1995).

${ }^{3}$ Map sources:

https://commons.wikimedia.org/wiki/File:Map_of_USA_showing_state_names.png https://commons.wikimedia.org/wiki/File:Map_of_Montana_highlighting_Richland_County.svg; https://commons.wikimedia.org/wiki/File:Map_of_North_Dakota_highlighting_Williams_Count y.svg.

${ }^{4}$ This question asked respondents whether they belong to a business group (e.g., Chamber of Commerce); civic, service, or fraternal organization (e.g., Elks, Kiwanis, Rotary, women's clubs, $4 \mathrm{H}$, or Scouts); local government (e.g., zoning, school, or conservation boards); or any other local organizations that have regular meetings.

${ }^{5}$ Community attachment is measured in the CERA survey using seven items asking respondents whether family, jobs, housing, education, recreational opportunities, natural beauty, and quality of life were important reasons for staying in their community $(0=$ not important; somewhat important $=1$; very important $=2$ ). Principal factoring with iterated communalities was used to identify two distinct dimensions (summated indexes) of attachment, practical and natural/life quality. Variables in the practical dimension include employment, housing, and education opportunities (Cronbach's alpha=0.69) and in the natural/life quality dimension includes recreational opportunities, natural beauty, and quality of life (Cronbach's alpha=0.70). The family attachment variable is not included in either index because it did not fit in either dimension. 


\section{References}

Anderson, B. J. \& Theodori, G.L. (2009). Local leaders' perceptions of energy development in the Barnett Shale. Southern Rural Sociology, 24(1), 113-129.

Archbold, C.A. (2015). Established-outsider relations, crime problems, and policing in oil boomtowns in Western North Dakota. Criminology, Criminal Justice, Law \& Society, 16(3), 19-40.

Archbold, C.A., Dahle, T. O. \& Jordan, R. (2014). Policing the patch: Police response to rapid population growth in oil boomtowns in Western North Dakota. Police Quarterly, 17(4), 386-413. https://doi.org/10.1177/1098611114549629

Bacigalupi, L. \& Freudenberg, W. (1983). Increased mental health caseloads in an energy boomtown. Administration in Mental Health, 10(4), 306-22. https://doi.org/10.1007/BF00823107

Brasier, K.J., Filteau, M. R., McLaughlin, D.K., Jacquet, J., Stedman, R.C., Kelsey, T.W. \& Goetz, S.J. (2011). Residents' perceptions of community and environmental impacts from development of natural gas in the Marcellus Shale: A comparison of Pennsylvania and New York cases. Journal of Rural Social Sciences, 26(1), 32-61.

Brown, T. (2011). The influence of rapid social change on civic community and perceptions of crime and disorder. International Journal of Rural Criminology, 1(1), 89-104. https://doi.org/10.18061/1811/51125

Carrington, K., Hogg, R., McIntosh, A. \& Scott, J. (2012). Crime talk, FIFO workers and cultural conflict on the mining boom frontier. Australian Humanities Review, 53, 1-14.

Devine-Wright, P. \& Howes, Y. (2010). Disruption to place attachment and the protection of restorative environments: A wind energy case study. Journal of Environmental Psychology, 30(3), 271-80. https://doi.org/10.1016/j.jenvp.2010.01.008

Dillman, D.A., Smyth, J.D. \& Melani Christian, L. 2014. Internet, phone, mail, and mixedmode surveys: The tailored design method (4th ed.). Hoboken, NJ: Wiley.

Duncan, C. M. (2015). Worlds apart: Poverty and politics in rural America (2nd ed). Yale University Press.

Durkheim, E. (1897). Suicide: A study of sociology. New York: Free Press.

Eligon, J. (2013, January 15). An oil town where men are many and women are hounded. New York Times. Retrieved from http://www.nytimes.com/2013/01/16/us/16women.html. 
Ellis, C., Theodori, G., Petrzelka, P., Jackson-Smith, D. \& Luloff, A. (2016). Unconventional risks: The experience of acute energy development in the Eagle Ford Shale. Energy Research and Social Science, 20, 91-98. https://doi.org/10.1016/j.erss.2016.05.006

Endo, R., Ellington, B. \& Nielsen, J.M. (1984). Wife abuse in western energy boomtowns. International Journal of Sociology of the Family, 14(2), 269-81.

England, J.L. \& Albrecht, S.L. (1984). Boomtowns and social disruption. Rural Sociology, 49(2), 230.

Evensen, D. \& Stedman, R. (2017). Beliefs about impacts matter little for attitudes on shale gas development. Energy Policy, 109, 10-21. https://doi.org/10.1016/j.enpol.2017.06.053

Faggiani, D. \& McLaughlin, C. (1999). Using national incident-based reporting system data for strategic crime analysis. Journal of Quantitative Criminology, 15(2), 181-191. https://doi.org/10.1023/A:1007574805500

Fernando, F.N., Ulrich-Schad, J.D. \& Larson, E.C. (Forthcoming). Methodological adaptations for conducting social science research during different stages of shale oil and gas development. In Theodori, G., Jacquet, J. \& Haggerty, J. (Eds.), Coordinating research on the social impacts of energy development: Synthesis across the social sciences. Boulder: University Press of Colorado.

Fernando, F. \& Cooley, D.R. (2015). An oil boom's effect on quality of life (QOL): Lessons from Western North Dakota. Applied Research in Quality of Life, 11(4), 1083-15. https://doi.org/10.1007/s11482-015-9422-y

Fernando, F. N. \& Cooley, D. R. (2016a). Socioeconomic system of the oil boom and rural community development in Western North Dakota. Rural Sociology, 81(3), 407-444. https://doi.org/10.1111/ruso.12100

Fernando, F.N. \& Cooley, D.R. (2016b). Attitudes toward shale oil development in western North Dakota: The role of place based community values in attitude formation. Journal of Rural Studies, 46, 132-146. https://doi.org/10.1016/j.jrurstud.2016.06.008

Freudenburg, W.R. (1984). Boomtown's youth: The differential impacts of rapid community growth on adolescents and adults. American Sociological Review, 49, 697-705. https://doi.org/10.2307/2095426

Freudenburg, W.R. (1982). The Impacts of rapid growth on the social and personal well-being of local community residents. In B.A. Weber \& R.E. Howell (Eds.), Coping with rapid growth in rural communities (pp. 137-70). Boulder: Westview.

Freudenburg, W.R. (1981). Women and men in an energy boomtown: Adjustment, alienation and adaptation. Rural Sociology, 46(2), 220-44. 
Freudenburg, W.R., Bacigalupi, L.M. \& Landoll-Young, C. (1982). Mental health consequences of rapid community growth: A report from the longitudinal study of boomtown mental health impacts. Journal of Health and Human Resources Administration, 4(3), 334-51.

Goldenburg, S. (2008). Youth sexual behavior in a boomtown: Implications for the control of sexually transmitted infections. Sexually Transmitted Infections, 84(3), 220-223. https://doi.org/10.1136/sti.2007.027219

Hamilton, L.C., Hamilton, L.R., Duncan, C. M. \& Colocousis, C.R. (2008). Place matters: Challenges and opportunities in four rural Americas. Reports on Rural America, 1(4).

Hamilton, L.C., Safford, T.G. \& Ulrich, J.D. 2012. In the wake of the spill: environmental views along the Gulf Coast. Social Science Quarterly, 93(4), 1053-1064. https://doi.org/10.1111/j.1540-6237.2012.00840.x

Horowitz, S. (2014, September 28). Dark side of the boom. Washington Post. Retrieved from http://www.washingtonpost.com/sf/national/2014/09/28/dark-side-of-theboom/?utm_term $=. f 4 d 382 \mathrm{c} 6 \mathrm{c} 865$

Hunter, L.M., Krannich, R. S. \& Smith, M.D. (2002). Rural migration, rapid growth, and fear of crime. Rural Sociology, 67(1), 71-89. https://doi.org/10.1111/j.1549-0831.2002.tb00094.x

Indian Law \& Order Commission (2013). A roadmap for making Native America safer. Los Angeles: Indian Law \& Order Commission.

Jacquet, J. \& Stedman, R.C. (2011). Natural gas landowner coalitions in New York State: Emerging benefits of collective natural resource management. Journal of Rural Social Sciences, 26(1), 62-91.

Jacquet, J. \& Stedman, R.C. (2013). Perceived impacts from wind farm and natural gas development in northern Pennsylvania. Rural Sociology, 78(4), 450-72. https://doi.org/10.1111/ruso.12022

James, A. \& Smith, B. (2014). There will be blood: Crime rates in shale-rich U.S. counties. Journal of Environmental Economics and Management, 84, 125-152. https://doi.org/10.1016/j.jeem.2016.12.004

Jones, M. (2016). Anomie in the oil patch? An examination of Durkheim's Anomie Theory through a case study of the Bakken region (Doctoral Dissertation). Retrieved from ProQuest Dissertations Publishing.

Junod, A.N., Jacquet, J.B., Fernando, F. \& Flage, L. (2018). Life in the Goldilocks Zone: Perceptions of place disruption on the periphery of the Bakken Shale. Society \& Natural Resources, 31(2), 200-217. https://doi.org/10.1080/08941920.2017.1376138 
Kennedy, L. \& Krahn, H. (1984). Rural-urban origin and fear of crime: The case of rural baggage. Rural Sociology(2), 49, 247-260.

Layne, K. (2013, October 3). Boomtown rats on the lonesome prairie. Gawker. Retrieved from http://gawker.com/boomtown-rats-on-the-lonesome-prairie-1440508492.

Malin, S. (2014). There's no real choice but to sign: Neoliberalization and normalization of hydraulic fracturing on Pennsylvania farmland. Journal of Environmental Studies and Sciences, 4(1), 17-27. https://doi.org/10.1007/s13412-013-0115-2

Maltz, M.D. (1999). Bridging gaps in police crime data: A discussion paper from the BJS Fellows program. Washington, DC: US Department of Justice.

Martin, K., Barrick, K., Richardson, N.J., Liao, D., \& Heller, D. 2019. Violent victimization known to law enforcement in the Bakken oil-producing region of Montana and North Dakota, 2006-2012. RTI International. Retrieved from https://www.ncjrs.gov/pdffiles 1/bjs/grants/252619.pdf

McGranahan, D.A. (1986). Crime and the countryside. Rural Development Perspectives, 2(2), 28.

Merrifield, J. (1984). Impact mitigation in western boomtowns. Growth and Change, 1(2), $23-8$. https://doi.org/10.1111/j.1468-2257.1984.tb00731.x

Munasib, A. \& Rickman, D.S. (2015). Regional economic impacts of the shale gas and tight oil boom: A synthetic control analysis. Regional Science and Urban Economics, 50, 1-17. https://doi.org/10.1016/j.regsciurbeco.2014.10.006

O’Connor, C.D. (2015). Insiders and outsiders: Social change, deviant others, and sense of community in a boomtown. International Journal of Comparative and Applied Criminal Justice, 39(3), 219-238. https://doi.org/10.1080/01924036.2014.973049

Park, M. \& Stokowski, P.A. (2009). Social disruption theory and crime in rural communities: Comparisons across three levels of tourism growth. Tourism Management, 30(6), 905-15. https://doi.org/10.1016/j.tourman.2008.11.015

Perry, S. (2012). Development, land use, and collective trauma: The Marcellus Shale gas boom in rural Pennsylvania. Culture, Agriculture, Food and Environment, 34(1), 81-92. https://doi.org/10.1111/j.2153-9561.2012.01066.x

Pooley, J.A., Cohen, L. \& Pike, L.T. (2004). Can sense of community inform social capital? The Social Science Journal, 42(1), 71-79. https://doi.org/10.1016/j.soscij.2004.11.006

Ruddell, R. (2011). Boomtown policing: Responding to the dark side of resource development. Policing, 5(4), 328-42. https://doi.org/10.1093/police/par034 
Ruddell, R., Jayasundara, D.S., Mayzer, R. \& Heitkamp, T. (2014). Drilling down: An examination of the boom-crime relationship in resource-based boom counties. Western Criminology Review, 15(1), 3-17.

Ruddell, R. \& Ortiz, N. (2014). Boomtown blues: Long-term community perceptions of crime and disorder. American Journal of Criminal Justice, 40(1), 129-146. https://doi.org/10.1007/s12103-014-9237-7

Safford, T.G., Henly, M., Ulrich-Schad, J.D. \& Perkins, K. 2014. Charting a future course for development: Natural resources, conservation, and community character in coastal Alaska. Journal of Rural and Community Development, 9(3), 21-41.

Safford, T.G., Ulrich, J.D., \& Hamilton, L.C. (2012). Public perceptions of the response to the Deepwater Horizon oil spill: Personal experiences, information sources, and social context. Journal of Environmental Management, 113, 31-39. https://doi.org/10.1016/j.jenvman.2012.08.022

Sangaramoorthy, T., Jamison, A.M., Boyle, M.D., Payne-Sturges, D.C., Sapkota, A., Milton, D.K. \& Wilson, S.M. (2016). Place-based perceptions of the impacts of fracking along the Marcellus Shale. Social Science \& Medicine, 151, 27-37. https://doi.org/10.1016/j.socscimed.2016.01.002

Scott, J., Carrington, K. \& McIntosh, A. (2012). Established-outsider relations and fear of crime in mining towns. Sociologia ruralis, 52(2), 147-169. https://doi.org/10.1111/j.14679523.2011.00557.x

Schafft, K., Borlu, Y. \& Glenna, L. (2013). The relationship between Marcellus Shale gas development in Pennsylvania and local perceptions of risk and opportunity. Rural Sociology, 78(2), 143-166. https://doi.org/10.1111/ruso.12004

Schafft, K., Glenna, L., Green, B. \& Borlu, Y. (2014). Local impacts of unconventional gas development within Pennsylvania's Marcellus Shale Region: gauging boomtown development through the perspectives of educational administrators. Society and Natural Resources 27(4), 389-404. https://doi.org/10.1080/08941920.2013.861561

Shandro, J.A., Veiga, M.M., Shoveller, J., Scoble, M. \& Koehoorn, M. (2011). Perspectives on community health issues and the mining boom-bust cycle. Resources Policy, 36(2), 178186. https://doi.org/10.1016/j.resourpol.2011.01.004

Shepard, S. E. (2013, July 25). Wildcatting: A Strippers guide to the modern American boomtown. Buzzfeed. Retrieved from https://www.buzzfeed.com/susanelizabethshepard/wildcatting-a-strippers-guide-to-themodern-american-boomtow?utm_term=.fgojDr1M1\#.vkjYm2dyd.

Stoneley, R. (1995). Introduction to Petroleum Exploration for Non-geologists. Oxford: Oxford University Press. 
Smith, M.D., Krannich, R.S. \& Hunter, L.M. (2001). Growth, decline, stability, and disruption: A longitudinal analysis of social well-being in four western rural communities. Rural Sociology, 66(3), 425-450. https://doi.org/10.1111/j.1549-0831.2001.tb00075.x

Theodori, G.L. (2009). Paradoxical perceptions of problems associated with unconventional natural gas development. Southern Rural Sociology, 24(5), 97-117.

Ulrich-Schad, J.D. \& Duncan, C.M. (2018). People and places left behind: Work, culture and politics in the rural United States. The Journal of Peasant Studies, 45(1), 59-79. https://doi.org/10.1080/03066150.2017.1410702

Ulrich-Schad, J.D. \& Qin, H. (2017). Culture clash? Predictors of views on community development in rural recreation counties. Rural Sociology, 83(1), 81-108. https://doi.org/10.1111/ruso.12165

Ulrich-Schad, J.D., Henly, M. \& Safford, T.G. (2013). The role of community assessments, place, and the great recession in the migration intentions of rural Americans. Rural Sociology, 78(3), 371-398. https://doi.org/10.1111/ruso.12016

Wayne S. (2012). A Summary of Uniform Crime Report Data. North Dakota Attorney General's Office. https://attorneygeneral.nd.gov/sites/ag/files/documents/2012CrimeReport.pdf

Wynveen, B.J. (2011). A thematic analysis of local respondents: Perceptions of Barnett Shale energy development. Journal of Rural Social Sciences, 26(1), 8-31. 